\title{
Architecture and typhlology. The potential of scientific partnership
}

\author{
Agnieszka Kłopotowska \\ https://orcid.org/0000-0002-4596-4052 \\ a.klopotowska@pb.edu.pl \\ Unit for Urban and Spatial Planning, Institute for Architecture and Urban Planning, \\ Department of Architecture, Bialystok University of Technology
}

\begin{abstract}
The connections between architecture and typhlology were not always obvious. Despite many related research problems, these sciences developed separately, and the study results of specialists from both departments did not reach the other discipline. An attempt to reduce this distance was made in the late decades of the $20^{\text {th }}$ century by Polish architects, aware of the possibility of solving specific problems of the blind through architectural activities.

The work is an attempt to constitute an interdisciplinary relationship between architecture and typhlology. The author indicates and names common issues important for both sciences, and also attempts to outline areas of their potential cooperation. In addition, she also highlights the values that can flow from this partnership.
\end{abstract}

Key words: visually impaired people, interdisciplinary research in architecture, universal design

The study has been implemented from the resources of the WZ/AiU/2/2020 public research funds financed by the Ministry of Science and Higher Education of Poland.

\section{Introduction. Research problem, purpose of publication, method}

The subject of the author's many years of scientific studies is the issue of relations between blind and visually impaired people and the spatial environment. Research covers various forms of extra-visual experience related to reception and active space on an urban, architectural and interior scale. The search for research includes issues such as:

- Specific problems and spatial barriers affecting blind people.

- Individual and environmental methods of compensating the spatial problems of the blind.

- The use of spatial relations as a link of so-called typhlorehabilitation (comprehensive rehabilitation and rehabilitation of the blind), with particular emphasis on the results of research with reflection and practicing art.

The study results to date have been presented by the author in a number of publications [Kłopotowska 2007,2009,2010,2015 (a), (b), (c)], including monographic studies [Kłopotowska 2016], [Kłopotowska, Kłopotowski 2018 (a), (b)].

The research required the author to go beyond the strict limits of the practiced architectural discipline and to enter the research fields of other sciences oriented at the subject of typhus (people with visual impairments). Interdisciplinary approach to the issues could not have been without the author's proper recognition of the "space of contact" of architecture and typhlology, including: identifying common problems and concepts, identifying information gaps and differences in scientific approaches. One of the problems noticed by the author during her preliminary research was the insufficient scientific empowerment of typhlology in architecture and architecture in typhlology. According to the author, this fact deserves a separate scientific comment. 
This text is an attempt to indicate the scientific relationship between architecture and typhlology. The author's intention is to outline areas of possible cooperation (exchange of knowledge and values) of both sciences and to highlight the advantages of this partnership. The research was based primarily on studies of multidisciplinary literature on the subject and an examination of the current state of research in the areas of specific sciences. The author also used verbally transferred knowledge and experience of a wide range of experts - theoreticians and practitioners representing knowledge-related areas of work. The author's personal scientific experience played a big role, allowing the confrontation of existing scientific views with her own beliefs.

\section{Research results. Discussion}

\section{Between architecture and typhlology}

Disciplinary clamps for conducted scientific research were: architecture - a discipline of science, classified in the field of engineering and technical sciences, at the same time manifesting a clear gravity towards the humanities and art, and typhlology - a department of science not yet having the status of a separate discipline and represented by a number of scientific departments (tyflopsychology, typhlorehabilitation, typhlopedagogy, techniques), inmates in the fields of medical sciences and health sciences, social sciences and engineering and technical sciences. The scientific bridge between the sciences is very wide and includes such branches of science as: psychology of architecture, psychology of perception, psychology of art, environmental psychology, art therapy, ergonomics, anthropology, sociology, humanistic geography, etc.

\section{Perspective of typhlopsychology}

Achievements of typhlopsychology (subdiscipline of psychology) have become the reference platform for author's research. The canon literature on the subject and the basis for later studies is the monographic publication of T. Majewski [Majewski 1983], referring to the work of M. Grzegorzewska [Grzegorzewska 1926]. It is significant that, when defining the departments of science supporting the development of typhoidology (medicine, ophthalmology, pedagogy, sociology, social sciences and technology), the author completely omits architecture as a potential partner discipline. In addition to the main accents of the work, the topic of the human-space relationship is also interesting to the author. This is probably due to the fact that psychology for a long time did not show interest in the impact of man on space and vice versa - space on the human psyche. The study of these issues is not an end in this area of science but merely a means to an end (psychological analysis and therapy). These issues, however, appear in the background of the author's considerations, primarily as descriptions of functional and developmental disorders within cognitive processes, spatial orientation, practical activity, motor skills and locomotion, and then descriptions of the possibilities of compensating these deficits by improving cognitive processes, practical activity and movement. On the other hand, issues related to the emotional perception of space are marginalized, which, according to the author, are an important element of social life (conditioning, among others, the use of art).

Significant differences are also manifested in scientific attitudes towards the problem of disability. Majewski's approach is "defectological" approach (aimed at catching deviations in the psychological structure of the blind), while the author is a supporter of the "rehabilitation" approach (referring, according to the philosophy of universal design, to what is common to all groups of space users).

\section{Perspective of typhlorehabilitation}

Typhlorehabilitation is a close author of the scientific attitude - practical science focused on achieving human well-being through reduction, elimination and compensation of deviations resulting from visual impairment. This science aims to lead to the maximum development of the individual but also to enable its social integration. The fundamental model of the so-called Polish School of Rehabilitation, assumes a harmonious development 
of all human needs (and therefore also spatial needs). The area of interest in joint typhlorehabilitation and architecture includes min. issues related to spatial orientation and locomotion. According to the author's research, typhlological knowledge in this area was developed, however, in isolation from architectural achievements [see: Lynch 2011, Kantarek 2013]. The rapid development of research on this subject became the result of global, multidisciplinary conferences in New York and Chicago $(1965,1969)$, dedicated to modern apparatus for sightless locomotion [PZN 1974]. Important topics for the architect are: E. Hill and P. Ponder [Hill, Ponder 1983] as well as texts by T. Majewski, which are the result of research in the United States [Majewski 1996]. The engineering and technology branch, associated with the development of orientation and locomotion equipment, is currently developing very rapidly, with Polish centers increasingly competing with foreign teams. It is worth recalling research and experiments carried out at such universities as: AGH University of Science and Technology in Kraków, Cracow University of Technology, Łódź, Gdańsk, Białostocka, Adam Mickiewicz University in Poznan. Another area common to typhlology and architecture is the issue of exploring space through various types of representations. From an architectural perspective, one of the most important achievements of typhlorehabilitation are tactile representations of architectural and urban space, including: emphasized plans, maps and three-dimensional models. Also this branch of typhlorehabilitation has evolved over many decades practically without the participation of architects. For a long time, these performances were mainly used as aids in route planning. The author also notices and popularizes their cognitive values (helpful in establishing deeper relationships with architectural art). This subject, in terms of architectural models and mockups, became the subject of a separate, detailed study of the author, conducted together with M. Kłopotowski and crowned with a two-volume monograph [Kłopotowska, Kłopotowski 2018 (a), (b)]. The work is practical and is an attempt to systematize the issues used to develop design and implementation standards. Specialist studies on the principles of creating typhlographics (semi-space drawings) were invaluable in formulating conclusions [Więckowska 2009]. The author's attention also focuses on acoustic methods to support orientation and locomotion as well as surrogate knowledge of the city space, including innovative research conducted at the Institute of Acoustics of the University of Adam Mickiewicz University in Poznan (2008-2010) [Kłopotowska (2) 2015].

\section{Perspective of typhlopedagogy}

The author's research has also become based on the extensive department of typhlopedagogy dealing with the issues of the education of the blind. This didactics is now understood as an integral component of rehabilitation. The result of such a defined research perspective is the perception of a blind person as a full human being able to develop and actively shape his fate.

In modern typhlopedagogy, there are currently two basic approaches to didactics. The first, referring to the tradition of special centers, envisages the education of blind people in specialized facilities. The second, developed since the 1980s [Hulek (ed.] 1992], is the so-called inclusive model, based on the so-called special education for blind and visually impaired students in schools or integration classes of general schools. This model is of particular interest to the author as an architectural problem of appropriate adaptation of educational institutions.

From the architect's perspective, an interesting typhlopedagogical issue are specialist pedagogical programs aimed at developing specific spatial skills, such as improving orientation and movement, and recognizing shapes, textures and sizes [Brown D., Simmons V., Methvin J. 1985], [Mangold SS 2000].

\section{Perspective of art therapy and art}

In the field of typhlorehabilitation knowledge, there is also a current associated with the so-called art therapy. This branch, pushed to the margins of science for a long time, is currently growing in popularity. In her research, the author particularly uses the work of E. Jutrzyna [Jutrzyna 2007]. The results of research in the field of music are an inspiration for the author to think about the possibility of using the resources of her own discipline for art therapy. 
The author's analyzes cover a wide spectrum of issues related to eye-catching and practicing art. This issue has still not been satisfactorily scientifically valid. An attempt to fill this gap is a publication devoted to the extra-visual perception of a work of art [Setlak 2015]. A significant practical achievement was an innovative educational project: "Study of Art Knowledge for People with Disabilities 2000/2001" - dedicated to min. people with sight impairments [Kłopotowska 2018]. A multidisciplinary conference entitled "Blind people and art" (Silesian Museum in Katowice, 2011). This meeting inspired the author to scientific travels to world centers promoting the sharing of art in Italy (Homer Museum in Ancona) and Spain (Typhoon Museum in Madrid). The author's research resulting from these trips strive to set the goals and directions of Polish anti-discrimination policy in the field of art and artistic education [Kłopotowska 2018].

\section{Architecture perspective}

Polish architects, such as H. Grabowska-Pałecka, K. Jaranowska, E. Kuryłowicz, E. Kuryłowicz, H. Skibniewska, demonstrated the awareness of the possibilities of architecture in solving specific problems of the blind in the $70 \mathrm{~s}, 80 \mathrm{~s}$ of the $20^{\text {th }}$ century. H. Zaniewska. In the following decades, min. architects: Z. Bogucka, M. Budlewska, B. Czarnecki, J. Jezierska, A. Kłopotowska, M. Wysocki.

The issues of tyflo have been developed for a long time in architecture in a wider stream of research on people with disabilities [Gałkowski 1986], Skibniewska H., Frąckiewicz. 1994], [Schwartz 1993], [Gałkowski 1996], [Jaranowska 1996], [Kuryłowicz 1996], [Omelańczuk I. (ed.) 2002]. Seminars and scientific conferences have become a sign of the growing interest of the architectural environment in the needs of people with disabilities, such as the seminar "Disabled in downtown Krakow" (1990), and the seminar "Creating common space. Urban and architectural problems of adapting space to the requirements of people with disabilities "(1995), seminars from the cycle:" Accessible space - design for all "(since 2002), conference" Disabled in Urban Space "(2005), conference" Architecture for all - friendly spaces of Europe "(2009), Polish Scientific-Training Conference," Personalized Medicine. Genom - Architecture - School - Design ", conference from the cycle Accessibility - Poland - City Available (2016) in Warsaw. Architectural competitions such as "Krakow without barriers", "Warsaw without barriers", "Gdańsk without barriers" organized by city and provincial governments, and the nationwide competition "Poland have become a valuable initiative encouraging the actual implementation of friendly solutions in architectural and urban space without barriers", initiated in 2009 by the Chancellery of the Sejm together with the Friends of Integration Association. An important element of the struggle for equality of all groups of users of urban space have also become European competitions addressed to future designers, including: the urban and architectural competition Schindler Award (cyclically since 2003), international student design workshops LOCUS (Let's Open Cities for Us), LOTUS (Let's Open Tourism for Us). Due to the author's research profile, the European workshop "Designing in Dark", which focuses on the problems of the blind, also deserves special attention. In the 90s - 2000s, architecture acquired valuable monographic studies popularizing the idea of universal design [Kuryłowicz 1996], [Grabowska-Pałecka 2004], [Wysocki 2010]. The novelty of these works was to redefine the concept of a disabled person (in accordance with the spirit of the philosophy of inclusive design, disability is the result of barriers in the spatial and social environment of man, not his physical, mental or mental disability) [Goldsmith 2000]. The authors broadly raise the topic of barriers in architectural space and look for ways and patterns to share the spatial environment with people with disabilities. All authors also raise the issue of access to cultural and art goods. Another pioneering work by M. Wysocki with a practical dimension, including the author's development of standards for spatial solutions in the city of Gdynia [Wysocki, doc. int.].

\section{Perspective of architecture psychology, psychology of perception}

Scientific support for the author were also publications in the field of architectural psychology - a relatively young (developed since the 1960s) branch of science focusing on observation of human relationships with the overall spatial environment. In a work devoted to the principles of this science, K. Lenartowicz shows architecture psychology as an extremely "open" science, drawing on the resources of many disciplines, but also perfectly co-creating other disciplines [Lenartowicz 1992]. Among the extensive, multidisciplinary bilbiography 
of architectural psychology, the following have become particularly helpful: existential trends [Ch. Norberg Szulz 2000], proxemic approach [E. T. Hall 2005] and the philosophical construct of experiencing space [Yi - Fu Tuan 1987], [S. E. Rasmussen 1999]. The author's special attention is drawn to the phenomenological texts of the architects: J. Pallasmaa - affirming the value of polisensory in human experience of architecture [Pallasmaa $2012,2016]$ and P. Zumthora [2010], catching the inseparable: bodily, psychological and spiritual relationships of man and architecture. An obvious reference point for the author's research were works in the field of psychology of perception [Gregory RL, 1971.], [Deręgowski 1990], [Gregory RL, Colman AM (ed.) 2002], including: perception and representation of the image and visual reception of art [ Strzemiński 1969], [Arnheim 2004, 2012]. The author found one of the few sources devoted to perception and tactile aesthetics (including in relation to the blind) in the research of M. Podgórski [Podgórski 2011]. The pretext for searching for visual concepts of learning about spatial reality has also become an original, interdisciplinary project entitled: "Sounds of architecture", dedicated to multi-faceted analyzes of the role of acoustic signals in the perception and use of architectural environment, implemented at the Faculty of Architecture of the Bialystok University of Technology (2014 - 2015) [Kłopotowska (2), (3) 2015].

\section{Conclusion}

\section{The value of typhlology in architecture}

The conducted research allowed to see a number of cognitive values resulting from the scientific empowerment of typhlological issues in architecture. Given the existing state of knowledge, the author stated that few works on the subject of the blind are part of a number of thematic areas present in the theory of architecture, such as: the availability of space at different scales for people with different perceptive and motor abilities; universal design; human safety and comfort in space as well as safety and ergonomics of the use of spatial forms; spatial orientation, movement and movement in space; mechanisms and methods of direct knowledge of space; mechanisms and methods of indirect knowledge of space through various types of representations; architectural education; didactics in the field of adapting space to the needs of people with disabilities; designing objects and spaces related to receiving and practicing art.

Trying to fill the gap she noticed, the author attempted to enrich these resources with a deepened, holistic and dynamic picture of the relationship between a blind person and the external environment. According to the author's belief, these issues are an important component of the discipline of science and architectural art, for which a thorough understanding of the nature of human encounters with space is a kind of background that determines all intervention and creation in space. Grasping, learning and effectively improving mechanisms that enable exploration and use of the spatial environment in conditions of permanent sight dysfunction, develop architects' key awareness of the needs and capabilities of various groups of users of the built space. The habit of broader understanding of the concept of "persons with disabilities" (instead of repenting to this day identifying disability with people in a wheelchair) can allow us to respond more wisely and more adequately to social needs, making architecture discipline closer to the real person and better embedded in European and global standards.

\section{The value of architecture in typhlology}

Despite many years of underestimating architecture as a partner discipline for typhlology, the potential of architecture in identifying and solving typhlological problems is enormous. The most obvious and, at the same time, the best scientifically researched field of practical use of architecture "in service" of typhlorehabilitation is shaping a friendly environment built, supporting the development and functioning of people with visual impairments and conducive to their social integration. The following issues should be mentioned: preventing and eliminating already existing architectural barriers, designing and implementing objects and spaces in a manner friendly to people with sight impairments. Skillful promotion and rewarding of so-called architects by the environment is also of great importance. good design patterns and vice versa, firm stigmatization of 
improper solutions. Architecture is also responsible for mature education, meeting European standards, of future designers and space decision makers at various scales, from the city scale, through architectural objects and spaces, to the interior scale.

In addition, the role of architects should be recognized as irreplaceable researchers of the spatial environment, which, properly shaped and organized, can become a rehabilitation environment for the disabled. In practice, this means the desirable (and often necessary!) Participation of architects in carrying out expertise of the availability of used and planned spatial investments, work in interdisciplinary bodies and legislative teams, improving the situation (legal and real) of users of various areas of space. In this aspect, it seems fundamental to lead (as in other European and world countries) to soon establish and implement appropriate accessibility standards, guaranteeing equal motor, cognitive, emotional access to places and spaces of social life. Another active aspect is the active participation of architects in the creation of appropriate substitute tools for learning about urban and architectural spaces (plans, models, audio description studies). In the era of constant insufficiency of scientific studies devoted to the subject of typhoid, the dissemination of scientific research results through publications and scientific conferences as well as educational activities directed at various entities responsible for the quality of the spatial environment (students, officials, authorities, administrators, etc.) are also very important. The role of architects as educators may also extend to specific tasks related to spatial education and artistic education of the blind. Such activities may include: organization of trainings, conferences, workshops and various types of artistic events targeted at this group of recipients, as well as architectural support of activities related to the broadly understood "opening" of educational and artistic institutions for the blind (including: adaptation of buildings, co-implementation various forms of education, design and implementation of appropriate typhlological aids).

\section{Summary}

The review of the most important research trends presented above, constituting the scientific horizons of the author's research, clearly illustrates the fluidity and interpenetration of the boundaries of individual sciences, shaping the current state of knowledge in the area of research. The author's review of the achievements of typhlology seems to indicate unequivocally that it was the mutual complementation of currents and scientific perspectives turned out to be for this young science a real "driving force generating acceleration and progress, observed over the last few decades. This fact seems to clearly indicate the need to continue the broad, interdisciplinary approach (which currently characterizes most contemporary scientific disciplines) and to further use typhlology from the achievements of other sciences, including strengthening its connections with architecture.

As with any science collaboration, the interdisciplinary cooperation of architecture and the extensive knowledge department covered by the common name of typhlology should be based on clearly establishing the principles of scientific interference and specifying the domains of both branches of science. Due to the well-being of the beneficiary of the given spatial solutions (burdened with a number of serious difficulties and limitations), both architects and typhologists must exercise "healthy" caution before entering the scientific competence of the second discipline. On the other hand, it seems indisputable that the use of knowledge and professional experience of representatives of the partner discipline can bring to each of the sciences a new, interesting view, but also specific practical values.

\section{Bibligraphy}

[1] Arnheim R., 2004: Sztuka i percepcja wzrokowa. Psychologia twórczego oka, przeł. J. Mach, Wydawnictwo słowo/ obraz terytoria, Gdańsk.

[2] Arnheim R., 2012: Myślenie wzrokowe, przeł. M. Chojnacki, Wydawnictwo słowo/ obraz terytoria, Gdańsk.

[3] Brown D., Simmons V., Methvin J., 1985: Oregoński program rehabilitacji niewidomych i stabowidzących dzieci w wieku od 0 do 6 lat, PZN, Warszawa.

[4] Deręgowski J. B., 1990: Oko i obraz. Studium psychologiczne, przeł. K. Dudziak, PWN, Warszawa. 
[5] Gałkowski A., 1986: Zadania architekta w projektowaniu miejsc pracy osób niepełnosprawnych, [w:] Hulek A. (red.) Człowiek niepetnosprawny w spoteczeństwie, Materiały II Kongresu TWK Warszawa 1-2 października 1983, Państwowy Zakład Wydawnictw Lekarskich, Warszawa, 359-361.

[6] Gałkowski A., 1996: Problemy barier architektonicznych i urbanistycznych [w:] Hulek A. (red), Człowiek niepetnosprawny w spoteczeństwie, PTWK, PZWL, Warszawa.

[7] Goldsmith S., 2000: Universal Design, Architectural Press, Oxford, Aucland, Boston, Johannesburg, Melbourne, New Delhi.

[8] Grabowska - Pałecka H., 2004: Niepetnosprawni w obszarach i obiektach zabytkowych. Problemy dostępności, Politechnika Krakowska, Kraków.

[9] Gregory R.L., Colman A. M. (red.), 2002: Czucie i percepcja, przeł. M. Siemiński, Zysk i S-ka Wydawnictwo, Poznań.

[10] Gregory R.L., 1971: Oko i mózg. Psychologia widzenia, przeł. S. Bogusławski, PWN, Warszawa.

[11] Hall E.T., 2005: Ukryty wymiar, Wydawnictwo MUZA S.A., Warszawa.

[12] Hill E., Ponder P., 1983: Orientacja i techniki poruszania się. Przewodnik dla praktyków, przeł. M. Jaśko, Polski Związek Niewidomych, Warszawa.

[13] Hulek A. (red.), 1992: Uczeń niepetnosprawny w szkole masowej, WSP, Kraków.

[14] Jaranowska K., 1996: Osoby niepetnosprawne w środowisku miejskim, COBO-Profil sp. z o.o., Warszawa.

[15] Jutrzyna E., 2007: Terapia muzyka w teorii i praktyce tyflologicznej, Polski Związek Niewidomych Zakład Nagrań i Wydawnictw, Warszawa.

[16] Kantarek A., 2013: O orientacji w przestrzeni miasta, Politechnika Krakowska, Kraków.

[17] Kłopotowska A., 2007: Niewidzialna architektura - status piękna w pozawzrokowej percepcji przestrzeni architektonicznej, [w:] „Czasopismo Techniczne. Architektura”, R.104., z. 13, 6-A/2007, 267-274.

[18] Kłopotowska A., 2009: Architektura w przekazie pozawzrokowym. Kształtowanie świadomej percepcji, [w:] „Czasopismo Techniczne. Architektura", R.106, z. 7, 1-A/2009, 331-339.

[19] Kłopotowska A., 2010: Przestrzeń do nauki przestrzeni. Sztuka projektowania przyjaznego osobom niewidomym i ociemniatym, [w:] "Czasopismo Techniczne. Architektura”, R.107, z. 15, 7-A/2010/2, 165-169.

[20] Kłopotowska A., 2013: Brajlon jako metoda zapisu przestrzeni architektonicznej w edukacji uczniów z dysfunkcją widzenia, [w:] Misiągiewicz M., Kozłowski D. (red.), Definiowanie Przestrzeni Architektonicznej. Zapis Przestrzeni Architektonicznej, T. II., Politechnika Krakowska, Kraków, 229-233.

[21] Kłopotowska A., 2015(a):, The Alphabet of Non - Visual Architecture - towards methodology of enabling people with visual impairment to participate in architectural play, [w:] „Czasopismo Techniczne. Architektura”, R.112, z. 9-A, $141-146$.

[22] Kłopotowska A., 2015(b):, Akustyczne obrazy przestrzeni miejskiej. Stuch jako narzędzie orientacji przestrzennej osób z dysfunkcją widzenia, [w:] Kłopotowska A. (red.), Dźwięki Architektury, Oficyna Wydawnicza Politechniki Białostockiej, Białystok.

[23] Kłopotowska A., 2015(c), Akustyczne obrazy przestrzeni miejskiej. Stuch jako narzędzie emocjonalnego odbioru przestrzeni u osób z dysfunkcją widzenia, [w:] Kłopotowska A. (red.), Dźwięki Architektury, Oficyna Wydawnicza Politechniki Białostockiej, Białystok.

[24] Kłopotowska A., 2016: Doświadczanie przestrzeni w rehabilitacji osób z dysfunkcja wzroku. Sztuka a tyflorehabilitacja, Białystok.

[25] Kłopotowska A., Kłopotowski M., 2018(a): Dotykowe modele architektoniczne w przestrzeniach polskich miast. Część I. Standardy, Oficyna Wydawnicza Politechniki Białostockiej, Białystok.

[26] Kłopotowska A., Kłopotowski M., 2018(b): Dotykowe modele architektoniczne w przestrzeniach polskich miast. Część I. Realizacje, Oficyna Wydawnicza Politechniki Białostockiej, Białystok.

[27] Kuryłowicz E., 1996: Projektowanie uniwersalne. Udostępnianie otoczenia osobom niepełnosprawnym, Centrum Badawczo - Rozwojowe Rehabilitacji Osób Niepełnosprawnych, Warszawa.

[28] Lenartowicz J. K., 1992: O psychologii architektury. Próba inwentaryzacji badań, zakres przedmiotowy i wpływ na architekturę, Politechnika Krakowska, Kraków.

[29] Majewski T., 1983: Psychologia niewidomych i niedowidzących, PWN, Warszawa.

[30] Majewski T., 1996: Poglądy na działalność Krajowej Federacji Niewidomych w Stanach Zjednoczonych, [w:] „Zeszyty Tyflologiczne", z. 14.

[31] Mangold S. S., 2000: MANGOLD - Rozwojowy Program Percepcji Dotykowej i Rozpoznawania Liter Brajlowskich, PZN, Warszawa.

[32] Norberg-Schulz Ch., 2000: Bycie, przestrzeń i architektura, Wydawnictwo Murator sp. z 0.0., Warszawa.

[33] Omelańczuk I. (red.), 2002: ABC...mieszkania bez barier, Fundacja "Dom dostępny”, Warszawa.

[34] Ostrowska M., 1991: Człowiek a rzeczywistość przestrzenna, Autorska Oficyna Wydawnicza Nauka i Życie, Szczecin. 
[35] Pallasmaa J., 2012: Oczy skóry. Architektura i zmysty, przeł. M. Choptiany, Instytut Architektury, Kraków.

[36] Pallasmaa J., 2016: Myśląca dłoń. Egzystencjalna i ucieleśniona mądrość w architekturze, przeł. M. Choptiany, Instytut Architektury, Kraków.

[37] Polski Związek Niewidomych, 1974: Wybrane zagadnienia z orientacji przestrzennej niewidomych, T. I., Warszawa.

[38] Polski Związek Niewidomych, 1974: Wybrane zagadnienia z orientacji przestrzennej niewidomych, T. II., Polski Związek Niewidomych, Warszawa.

[39] Rasmussen S.E., 1999, Odczuwanie architektury, przeł. B. Gadomska, Wydawnictwo Murator, Warszawa.

[40] Schwartz L, 1993: Projektowanie środowiska w świetle potrzeb osób z uszkodzonym narządem wzroku, [w:] „Przegląd Tyflologiczny", nr 1-2, 32-53.

[41] Setlak R., Percepcja dzieła sztuki przez osoby z dysfunkcją narządu wzroku, Gdańsk 2015.

[42] Skibniewska H., Frąckiewicz L. (red.), 1994: Środowisko zamieszkania a niepełnosprawni, Wydawnictwo Instytutu Filozofii i Socjologii PAN, Warszawa.

[43] Skibniewska H., Schneider P., 1984: Niepełnosprawni w środowisku mieszkalnym. Mieszkania i zabudowa. Wytyczne do projektowania. Zeszyt 4., COSPBM "Inwestprojekt", Warszawa 1984.

[44] Strzemiński W., 1969: Teoria widzenia, Wydawnictwo Literackie, Kraków.

[45] Tuan Yi-Fu, 1987: Przestrzeń i miejsce, przeł. A. Morawińska, PIW, Warszawa.

[46] Więckowska E., Zasady redagowania tyflografiki [w:] „Tyfloświat” 2009, nr 3(5), s. 7-13.

[47] Wysocki M., 2010: Projektowanie otoczenia dla osób niewidomych. Pozawzrokowa percepcja przestrzeni, Wydawnictwa Politechniki Gdańskiej, Gdańsk.

[48] Wysocki M., Standardy dostępności dla miasta Gdyni, https://www.zdiz.gdynia.pl/dokumenty/ud/standardy.pdf, stan z dn. 11.12.2019.

[49] Zaniewska H. (red.), 2001: Mieszkania starszych ludzi w Polsce. Sytuacja i perspektywy zmian, Instytut Gospodarki Mieszkaniowej, Warszawa.

[50] Zumthor P., 2010: Myślenie Architekturq, Karakter, Kraków. 